\title{
Editorial
}

\section{EU law and regulation of private health insurance}

\author{
SARAH THOMSON* \\ Research Fellow in Health Policy, London School of Economics and Political Science \\ ELIAS MOSSIALOS \\ Professor of Health Policy, London School of Economics and Political Science
}

The influence of European Union (EU) law on private health insurance has not received as much attention as its impact on other parts of the health system (Hervey, 2007). Now is a good time to redress this relative neglect, as growing interest in private health insurance - in particular, its potential to relieve pressure on public budgets and enhance choice - raises questions about how best to create or expand and shape markets to achieve specific aims. There are no easy answers to these questions, but one thing seems clear: if policy makers intend to use private health insurance to achieve a particular objective, they must be able to direct market behaviour appropriately. Otherwise, the type of market most likely to emerge is one that simply provides access to acute care in the private sector for wealthier people. However, in newer markets lack of regulatory capacity often presents a barrier to effective policy direction (Thomson et al., 2007 forthcoming). In the established markets of the EU, many of the constraints facing policy makers come from single market legislation. Here we use the case of the Third Non-Life Insurance Directive to illustrate some of these constraints and to show how they can undermine the achievement of health policy goals such as financial protection, equity of access to health care and quality or efficiency in the organization, administration, and delivery of health services.

In 1992, the European Commission set out its framework for regulation of health insurance in EU member states. Prior to this, health insurance had been excluded from single market legislation, along with other forms of 'mass risks' involving individuals and small businesses, on the grounds that its complex nature required special protection. To facilitate the free movement of insurance services, the Third Non-Life Insurance Directive extended single market

\footnotetext{
*Corresponding author: Research Fellow in Health Policy, European Observatory on Health Systems and Policies and LSE Health, London School of Economics and Political Science, Houghton Street, London, WC2A 2AE, UK. Tel: +44-20-7955-6474; Email: s.thomson@lse.ac.uk
} 
legislation to all risks. The Directive exempts health insurance that forms part of a national system of social security from its stipulations (Hatzopoulos, 2002). ${ }^{1}$ However, it has meant the following changes for private health insurance: it requires governments to liberalize markets, opening them up to competition at national and EU levels; it prevents governments from applying any form of material regulation involving product and price controls, permitting only financial regulation; it sets minimum solvency levels; and it prohibits any form of discrimination among insurers (through regulatory or fiscal means) on the basis of legal status (Thomson and Mossialos, 2007).

At the time of the Directive - as now - private health insurance did not constitute more than 5 per cent of total expenditure in most EU member states. It was thought to play a relatively minor role, either 'complementing' statutory health insurance (by covering user charges or services excluded from the publicly financed benefits package - dental care, for example) or 'supplementing' it (by providing greater choice of provider and/or faster access to health care) (Mossialos and Thomson, 2002). But there were a few countries in which it played a much greater role, providing 'substitutive' cover for groups who were excluded from some aspects of the means-tested statutory health insurance scheme (Ireland and the Netherlands) or allowed people to opt out of it (Germany). Because private health insurance in these countries was heavily regulated, policy makers were sufficiently concerned to negotiate with the European Commission before the Directive was issued (Association Internationale de la Mutualité, 1999). The result was Article 54.1, which states that the regulatory authority may impose measures in the interest of the 'general good' - to protect consumers - if contracts covering health risks 'serve as a partial or complete alternative to health cover provided by the statutory social security system' (European Communities, 1992). Article 54.2 and recitals to the Directive list the measures regulators can introduce under such circumstances: open enrolment, community rating, lifetime cover, policies standardized to match statutory benefits packages (at or below a prescribed maximum premium rate), risk equalization schemes, and operating private health insurance on a funded basis similar to life insurance. The Irish government already had a derogation from the First Non-Life Insurance Directive's solvency requirements for its quasi-state insurer Vhi Healthcare, and this remained (Competition Authority, 2007).

The Directive had little immediate impact in most countries. National legislative amendments generally involved the introduction of tighter solvency controls or, in a few cases, the abolition of product and price controls (Thomson and Mossialos, 2007). However, its impact in Ireland was substantial from

1 European Court of Justice case law confirms that insurance activities fall under the scope of the Directive when they are carried out by insurance undertakings at their own risk, following insurance techniques and on the basis of contractual relationships governed by private law. 
the outset, requiring the Irish government to open up its market to competition. In other contexts its impact has grown over time, partly because the European Commission has been reluctant to clarify areas of legal uncertainty, partly because affected stakeholders have been slow to put forward cases and partly due to changes in statutory health insurance arrangements. This last factor is especially likely to create problems in future.

Although the Directive seems to give governments scope to regulate private health insurance to protect consumers, there is no agreed definition of the general good. As a result there is uncertainty about when governments can intervene and what measures they can introduce (Thomson and Mossialos, 2007). This uncertainty is compounded because interpretation of the general good relies on the case law of the European Court of Justice (ECJ) and the process of testing questionable use of the principle in the courts is both lengthy and expensive. A government's ability to engage in material regulation hinges on whether a market for private health insurance serves as a partial or complete alternative to statutory health insurance. Circumstantial factors suggest that only markets that play a substitutive role fall into this category. Not only was article 54.1 the direct result of lobbying by governments in countries with substitutive markets (Association Internationale de la Mutualité, 1999), the regulatory measures set out in article 54.2 are an exact match of the measures in place in those countries at that time.

Further light comes from correspondence between the Dutch Ministry of Health and the then Commissioner for the Internal market, Frits Bolkestein (Bolkestein, 2003; Hoogervorst, 2003a and b). Letters exchanged by the two parties prior to the health insurance reforms introduced in the Netherlands in 2006 confirm two key points. First, only a substitutive market would constitute an 'alternative' to statutory health insurance, because only a substitutive market would 'replace' statutory benefits. Second, the distinction between partial and complete is to be understood in terms of the benefits provided by substitutive cover; 'partial' might refer to cover of outpatient care alone, whereas 'complete' might refer to cover of outpatient and inpatient care. The underlying logic here is that material regulation is only necessary to protect consumers in substitutive markets because non-substitutive markets do not provide individuals with social protection. But complementary private health insurance can also contribute to social protection; 'partial alternative' could therefore be interpreted in other ways. For example, if the benefits covered by statutory health insurance are relatively narrow or subject to extensive user charges, then individuals would not be fully protected from financial risk unless they were able to purchase complementary cover. This seems to have been the view of the French government, whose concern for the welfare of the 15 per cent of the population who did not have complementary cover of user charges led them to introduce free cover for people with low incomes (from 2000). However, under the Directive's framework, material regulation to protect 
consumers purchasing complementary cover is likely to be at best controversial, at worst illegal.

Take the case of Ireland. Following the opening of its market to competition in 1994, the Irish government introduced rules similar to the ones that had previously applied to the dominant insurer Vhi Healthcare (open enrolment, community rating, and lifetime cover). It also introduced new rules such as the possibility of introducing a risk equalization scheme, should the need for it arise. Two other insurers have since entered the market: BUPA Ireland, a non-profit subsidiary of the largest health insurer in the United Kingdom (in 1997) and a commercial Irish company, Vivas (in 2004). The government activated the risk equalization scheme in 2006 on the advice of the regulatory authority, prompting a domestic legal challenge by BUPA. But the scheme had been a source of contention since 1998, when BUPA complained to the European Commission - unsuccessfully - that risk equalization payments to Vhi Healthcare would constitute state aid (European Commission, 2003a). In 2007, BUPA pulled out of the Irish market, but the legal challenges continue, both in the Irish courts and at EU level. Earlier this year the European Commission began infringement proceedings against the Irish government in response to Vivas' claim that Vhi Healthcare had breached the conditions of its derogation from the Directive by carrying out business in addition to its core health insurance activity (European Commission, 2007).

Two things are interesting about the furore surrounding private health insurance in Ireland. First, legal challenges have focused on risk equalization rather than open enrolment and community rating, but risk equalization would be difficult to justify in the absence of the latter requirements. Perhaps insurers have not wanted to be seen to be criticizing measures so obviously intended to ensure equity of access to private health insurance. Second, legal challenges have not focused on the issue of whether or not the Irish market constitutes a partial or complete alternative to statutory health insurance. Vhi Healthcare was originally established in the 1950 s to cover the 15 per cent of the population who were not eligible for publicly financed hospital care. But by 1991 the Irish government had introduced universal entitlement to free treatment in public hospitals and by 2006 there was also universal entitlement to outpatient services (subject to a maximum co-payment of $€ 550$ per year for richer households). Private health insurance no longer plays a substitutive role as it only covers the costs of treatment in the private sector (a supplementary role) and part of the costs of outpatient care (a complementary role). The current regulatory framework therefore seems at odds with the Directive. However, the European Commission carefully sidestepped the issue in 2003, when it rejected BUPA Ireland's complaint about state aid (European Commission, 2003b). In fact, it emphasized that it made its decision independently of any consideration as to whether the Irish market could be regarded as a partial or complete alternative. And the Irish government may be concerned about the implications 
of dismantling such a framework for the 50 per cent of the population who purchase private cover and for the private hospitals for which private health insurance is a major source of income.

Risk equalization has also been controversial in Slovenia, where complementary private health insurance covering user charges is purchased by three quarters of the population. In 2005, the Slovenian government passed legislation requiring insurers to offer open enrolment and community-rated premiums accompanied by a risk equalization scheme. It did so to protect established insurers operating on the basis of community rating from being undermined by a new entrant to the market who offered risk-rated premiums. The risk equalization scheme was unpopular with the incumbent insurers, who challenged it in the courts, although neither case made mention of the Directive. The courts eventually decided in favour of the government.

Beyond the issue of risk equalization, the main area of contention has been the Directive's prohibition of differential treatment of insurers. This prevents policy makers from influencing market structure by showing preferential tax treatment to non-profit insurers or by restricting the provision of private health insurance to certain types of insurer (for example, specialist health insurers in Germany, a single approved insurer in Ireland prior to 1994, statutory health insurance funds in Slovenia prior to 1999 or non-profit insurers). In general, there are good reasons for prohibiting discriminatory behaviour. But in some instances the ability to reward appropriate conduct might ensure access for disadvantaged groups (notably older and poorer people). In other cases the ability to restrict the sale of insurance to established entities such as statutory health insurance funds, even for a limited time, might be an important means of forging consumer trust in new markets (for example, in some former Soviet Union countries, where dubious business practices had eroded public confidence in insurance schemes) (Thomson et al., 2007 forthcoming). In 1999, the European Court of Justice ruled against the French government's policy of allowing mutual insurers to operate with lower solvency levels than commercial insurers and in 2006 the European Commission began infringement proceedings against the Belgian government for the same reason (European Commission, 2000; European Commission, 2006).

The Directive's restrictions on material regulation have also emerged as an issue owing to reforms to statutory health insurance arrangements. In Ireland, it was the gradual expansion of eligibility for statutory health insurance that changed the role played by private health insurance. Whether or not the regulatory framework originally intended to support a substitutive role is compatible with the Directive now that this role has changed is a matter of debate. In the Netherlands there have been concerns about the application of the Directive to the universal system of health insurance (introduced in 2006), which is governed by private law. Although the European Commission seems satisfied that the new system constitutes a complete alternative to statutory health insurance, 
doubts remain about the wisdom of relying on Article 54.1 to justify a national regulatory framework. Legal challenges are still a possibility.

Reforms extending choice of sickness fund in Germany and the Netherlands have created new incentives for insurers to use private health insurance as a tool for risk selection in statutory health insurance through a practice known as conditional sale. Because some insurers sell both statutory and private health insurance (or belong to holding companies consisting of statutory and private insurers), they can terminate complementary or supplementary contracts when subscribers opt to buy statutory cover from another company. This means that free choice of sickness fund is not in practice a reality for some groups usually older or chronically ill people - who would find it difficult to obtain private cover with a new insurer; many would face substantially higher premiums or the exclusion of pre-existing conditions and some might actually be refused cover outright. Conditional sale is not yet a major issue in either country. However, it has severely limited choice of sickness fund in Switzerland and could prove problematic in future, particularly if the cover provided by private health insurance gains in importance (for example, following attempts to narrow the publicly financed package of benefits) (Paolucci et al., 2007).

Controversy caused by the Directive highlights some - but by no means all of the risks associated with the use of private health insurance, even in contexts where regulatory capacity is not an issue. It shows the importance of anticipating changes in market role, structure, and conduct. Far from being static entities, markets change over time, often in response to developments in the publicly financed system, to which they tend to be highly sensitive. The EU experience also draws attention to the potential danger of introducing 'temporary' measures to serve short-term goals such as shifting costs to private entities. Once established, institutions are likely to become entrenched, which may foreclose some policy options. For example, the role played by private insurers in the previously substitutive market in the Netherlands may have influenced the government's decision to opt for a universal private rather than public system, while in Germany the presence of private insurers as powerful stakeholders has inhibited moves towards universal coverage through statutory health insurance (Thomson and Mossialos, 2006).

The Directive reflects the institutional norms of its time. In 1992, the European Commission may have thought that Article 54 would provide ample protection for consumers in substitutive markets, while the benefits of competition (more choice, lower prices) would outweigh concerns for consumer protection in other markets. These assumptions are more problematic now, partly because there is little evidence to suggest that the expected benefits of competition have materialized. Solvency rules alone do not seem sufficient to protect consumers in non-substitutive markets if, for example, health insurance products are highly differentiated. Reports point to growing information asymmetry and consumer detriment in several markets and the European 
Commission has not yet put in place mechanisms to monitor anti-competitive behaviour by insurers (Office of Fair Trading, 1998; Organization for Economic Co-operation and Development, 2001). More important, perhaps, are problems arising from increased blurring of the boundaries between economic activity and social security, particularly since the latter is no longer the preserve of publicly financed statutory institutions. As governments look to private health insurance to relieve pressure on public budgets, uncertainty and unease about the Directive's scope and impact are likely to grow.

\section{References}

Association Internationale de la Mutualité (1999), 'Towards a fourth generation of European insurance directives?', Aims (newsletter of the Association Internationale de la Mutualité), 5(March): 1-3.

Bolkestein, F. (2003), Letter from the European Commission to the Dutch Minister of Health, Welfare and Sport, 25 November 2003, Ministry of Health, Welfare and Sport, The Hague.

Competition Authority (2007), Competition in the Private Health Insurance Market, Dublin: The Competition Authority.

European Commission (2000), 'Insurance: infringement proceedings against France concerning mutual societies and the requirement of a marketing information sheet' (press release 28 July 2000), European Commission, Brussels.

European Commission (2003a), 'Green light for the introduction of a risk equalisation scheme in the Irish health insurance market' (press release 13 May 2003), European Commission, Brussels.

European Commission (2003b), 'State Aid N 46/2003 - Ireland - Risk equalisation scheme in the Irish health insurance market', European Commission, Brussels.

European Commission (2006), 'Commission scrutinises Belgian law on supplementary health insurance provided by private sickness funds', European Commission, Brussels.

European Commission (2007), 'Insurance: Commission scrutinises exemption of Irish Voluntary Health Insurance Board from EU rules', European Commission, Brussels.

European Communities (1992), 'Council Directive 92/49/EEC of 18 June 1992 on the coordination of laws, regulations and administrative provisions relating to direct insurance other than life assurance and amending Directives 73/239/EEC and 88/357/EEC (Third non-life insurance directive)', Official Journal of the European Community, 50 (11 August 1992): 1-23.

Hatzopoulos, V. (2002), 'Do the rules on internal market affect national health care systems?', The Impact of EU Law on Health Care Systems, M. McKee, E. Mossialos, and R. Baeten (eds), Brussels: P.I.E.-Peter Lang, pp. 123-160.

Hervey, T. (2007), 'EU law and national health policies: problem or opportunity?', Health Economics, Policy and Law, 2(1): 1-6.

Hoogervorst, H. (2003a), Letter from the Dutch Minister of Health, Welfare and Sport to the European Commissioner for the Internal Market, 8 October 2003, Ministry of Health, Welfare and Sport, The Hague. 
Hoogervorst, H. (2003b), Letter from the Dutch Minister of Health, Welfare and Sport to the European Commissioner for the Internal Market, 19 December 2003, Ministry of Health, Welfare and Sport, The Hague.

Mossialos, E. and S. Thomson (2002), 'Voluntary health insurance in the European Union: a critical assessment', International Journal of Health Services, 32(1): 19-88.

Office of Fair Trading (1998), Health Insurance: A Second Report by the Office of Fair Trading, London: Office of Fair Trading.

Organization for Economic Co-operation and Development (2001), Private Health Insurance In OECD Countries: Compilation of National Reports, Paris: OECD.

Paolucci, F., E. Schut, K. Beck, S. Greß, C. Van de Voorde, and I. Zmora (2007), 'Supplementary health insurance as a tool for risk selection in mandatory basic health insurance markets: a five country comparison', Health Economics, Policy and Law, 2(2): [page numbers to be inserted - this issue].

Thomson, S. et al. (2007 forthcoming), 'What role for voluntary health insurance?', in J. Kutzin, R. Busse, and J. Schreyögg, Implementing Health Financing Reforms: Lessons from and for Countries in Transition, Maidenhead: Open University Press.

Thomson, S. and E. Mossialos (2006), 'Choice of public or private health insurance: learning from the experience of Germany and the Netherlands', Journal of European Social Policy, 16(4): 315-327.

Thomson, S. and E. Mossialos (2007), 'Regulating private health insurance in the European Union: the implications of single market legislation and competition policy', Journal of European Integration, 29(1): 89-107. 